\title{
UPAYA MENINGKATKAN HASIL BELAJAR IPA DENGAN MODEL PEIMBELAJARAN SCRAMBLE-IMEDIA VISUAL PESERTA DIDIK KELAS IV SDN 4 PANARUNG TAHUN PELAJARAN 2017/2018
}

\author{
Effort Increasing Learning Results with Scramble-Visual Media Learning Model on \\ Participants $4^{\text {th }}$ Grade $4^{\text {th }}$ Panarung Elementary School Lesson Year 2017/2018
}

\author{
'Rahmi Yantol, ${ }^{2}$ Diplan, \& ${ }^{3 *}$ Nurul Hikmah Kartini \\ IStudent in Elementary Teacher Education, Universitas Muhammadiyah Palangkaraya, RTA Milono St. Km. I,5, Palangka Raya, Indonesia \\ 2Senior Lecturer in Elementary Teacher Education, Universitas Muhammadiyah Palangkaraya, RTA Milono St. Km. I,5, Palangka Raya, \\ Indonesia \\ ${ }^{3}$ Lecturer in Elementary Teacher Education, Universitas Muhammadiyah Palangkaraya, RTA Milono St. Km.I,5, Palangka Raya, Indonesia
}

*e-mail : nurulkartini77@gmail.com

\begin{abstract}
ABSTRAK
Penelitian ini bertujuan untuk: (I) mendeskripsikan aktivitas belajar peserta didik kelas IV SDN 4 Panarung pada saat pembelajaran IPA dengan menggunakan model pembelajaran Scramble berbantuan media Visual, (2) mengetahui hasil belajar IPA peserta didik kelas IV SDN 4 Panarung dengan menggunakan model pembelajaran Scramble berbantuan media Visual. Metode dan jenis penelitian yang digunakan dalam penelitian ini adalah Penelitian Tindakan Kelas (PTK). Hasil penelitian menunjukkan bahwa: (I) Aktivitas belajar peserta didik pada kategori baik mejadi lebih baik dalam pembelajaran IPA dengan menggunakan model pembelajaran scramble berbantuan media visual di kelas IV SDN 4 Panarung tahun pelajaran 2017/20I8. Peserta didik berperan aktif, termotivasi, saling bekerjasama dengan meningkatkan konsentrasi dan kecepatan berfikir selama proses pembelajaran pada siklus I. Hasil pengamat aktivitas guru pada proses pembelajaran yang dilakukan oleh pengamat I dan pengamat II selama proses pembelajaran ilmu pengetahuan alam (IPA) pada siklus I rata-rata aktivitas guru yaitu 3,61 dengan kriteria sangat baik dan rata-rata aktivitas peserta didik yaitu 3,55 dengan kriteria sangat baik. (2) Ada peningkatan hasil belajar IPA peserta didik kelas IV di SDN 4 Panarung tahun pelajaran 2017/20I8 setelah menggunakan model pembelajaran scramble dengan berbantuan media visual. Hal ini ditunjukkan hasil belajar melalui skor rata-rata kelas pada tes awal yaitu 43 dan persentase ketuntasan belajar peserta didik secara klasikal yaitu 9,52\% dengan kriteria tidak tercapai. Pada siklus I skor rata-rata kelas yaitu 70 dan persentase ketuntasan belajar peserta didik secara klasikal yaitu 100\%, dari kriteria yang telah ditentukan yaitu KKM adalah 65 dan kriteria ketuntasan secara klasikal $85 \%$ dengan kategori tercapai.
\end{abstract}

Kata kunci: Scramble, Media Visual, Hasil Belajar IPA

\begin{abstract}
This study aims to: (I) describe the learning activities of grade 4 students of SDN 4 Panarung at the time of science teaching using Scramble-Visual media, (2) to know the learning outcomes of science students of grade IV SDN 4 Panarung by using the learning model Scramble-Visual media. The method and type of research used in this research is Classroom Action Research (PTK). The results showed that: (I) Students' learning activities in good category became better in science lesson using visual media assisted media scramble model in fourth grade of SDN 4 Panarung in academic year 2017/2018. Learners play an active role, motivated, cooperate with each other to improve the concentration and speed of thinking during the learning process in cycle $I$. The results of observers of teacher activity on the learning process conducted by observers I and observer II during the process of learning science (natural) the teacher activity is 3.61 with very good criteria and the average activity of learners is 3.55 with very good criteria. (2) There is an improvement of science learning outcomes of students of class IV in SDN 4 Panarung academic year 2017/2018 after using the model of learning scramble with visual media assisted. This shows the results of learning through the average score of the class on the initial test is 43 and the percentage of learning mastery learners classically $9.52 \%$ with the criteria not achieved. In the first cycle, the average score of the class is 70 and the percentage of students' learning completeness classically is $100 \%$, from the predetermined criteria that is $K K M$ is 65 and the criteria completeness $85 \%$ classically achieved category.
\end{abstract}

Keywords: Scramble, Visual Media, Science-Learning Results

\section{PENDAHULUAN}

Pendidikan merupakan usaha sadar yang diarahkan untuk mencapai suatu perbaikan di segala aspek kehidupan. Serta untuk merubah tingkah laku agar lebih baik. Oleh karena itu, pada dasarnya manusia juga mempunyai potensi untuk menjadi lebih baik lagi. Maka diperlukan usaha sadar untuk mewujudkan harkat dan martabat kemanusiaan yang tertinggal pada masing-masing individu. Hal ini didukung oleh tujuan pendidikan yang tercantum dalam UndangUndang Republik Indonesia No. 20 tahun 2003 tentang Sistem Pendidikan Nasional Pasal I ayat (I) yang menyatakan bahwa:

Pendidikan adalah usaha sadar dan terencana untuk mewujudkan suasana belajar dan proses pembelajaran 
dengan peserta didik secara aktif membangun potensi dirinya untuk memahami kekuatan spiritual keagamaan, pengendalian diri, kepribadian, kecerdasan, akhlak mulia serta keterampilan yang diperlukan dirinya, masyarakat, bangsa, dan Negara.

Untuk memperbaiki tingkat dan kompetensi pendidikan di Indonesia, maka pemerintah mengeluarkan Peraturan Pemerintah No.19 tahun 2005 tentang Standar Nasional Pendidikan. Standar Pendidikan Nasional terdiri dari 8 komponen yaitu: (I) Standar Isi, (2) Standar Proses, (3) Standar Kompetensi Lulusan, (4) Standar Pendidik dan Tenaga Kependidikan, (5) Standar Sarana dan Prasarana, (6) Standar Pengelolaan, (7) Standar Pembiayaan, dan (8) Standar Penilaian Pendidikan. Dari 8 Standar Nasional Pendidikan agar dapat tercapai. oleh guru untuk membimbing dan mengajar peserta didik supaya peserta didik dapat meningkatkan pengetahuan pendidikan.

Menurut Peraturan Pemerintah Nomor 19 Tahun 2005 tentang Standar Nasional Pendidikan, dinyatakan bahwa Standar Pendidikan berfungsi sebagai dasar dalam perencanaan, pelaksanaan dan pengawasan pendidikan dalam rangka mewujudkan pendidikan nasional yang bermutu yang bertujuan untuk menjamin mutu pendidikan nasional yang dapat mencerdaskan kehidupan bangsa dan membentuk watak serta peradaban bangsa yang bermartabat (Pasal 3 dan 4).

Standar Nasional Pendidikan merupakan kriteria minimal tentang system pendidikan diseluruh wilayah hukum Negara Kesatuan Republik Indonesia (Pasal I PP No. 19 Tahun 2007) untuk meningkatkan mutu sumber daya manusia dan pengukuran kualitas pendidikan. Standar tersebut bukan merupakan ukuran yang statis yang tidak berubah, tetapi semakin lama semakin ditingkatkan. Selain itu standar pendidikan juga berfungsi sebagai pemetaan pendidikan yang bermutu.

Untuk mewujudkan hal tersebut maka faktor guru memiliki peran yang sangat penting dalam dunia pendidikan. Guru merupakan ujung tombak terdepan dalam menentukan keberhasilan peserta didik. Oleh karena itu, guru dituntut untuk memiliki keterampilan serta kemampuan dalam mengelola proses pembelajaran secara profesional. Guru profesional hendaknya mampu melaksanakan tanggung jawab sebagai guru kepada peserta didik.

Keterampilan yang harus dimiliki oleh seorang guru khususnya guru IPA yaitu selain dapat memahami kebutuhan dan karakteristik peserta didik, juga dapat membaca situasi dan kondisi, dan dapat menguasai materi pembelajaran dengan baik, serta menguasai strategi atau pendekatan dan memilih pendekatan yang cocok dengan materi yang akan diajarkan.
IPA merupakan program untuk menanamkan dan mengembangkan pengetahuan, keterampilan, sikap, dan nilai ilmiah pada peserta didik. Berdasarkan definisi ini, maka idealnya pembelajaran IPA membantu peserta didik memahami konsep IPA dan keterkaitannya dengan kehidupan sehari-hari. Oleh karena itu, dalam pembelajaran IPA seharusnya diciptakan kondisi yang menyengkan agar peserta didik selalu aktif dalam mengikuti pembelajaran khususnya mata pelajaran IPA. Dalam pembelajaran IPA di sekolah dasar, guru sangat berperan dalam meningkatkan hasil belajar peserta didik, karena pada kenyataannya pembelajaran IPA sering dihadapkan pada masalah hasil belajar peserta didik rendah terhadap materi sebelumnya.

Akibatnya, tujuan pembelajaran yang telah ditetapkan tidak dapat tercapai secara maksimal dan berpengaruh terhadap hasil belajar peserta didik. Untuk meningkatkan hasil belajar peserta didik yaitu salah satunya dengan cara pemilihan model, dan media yang tepat dalam pembelajaran. Dan penggunaan berbagai model, dan media dalam pembelajaran mempunyai peran yang besar terhadap pencapaian tujuan pembelajaran. Untuk menciptakan suasana belajar yang menarik, seorang guru membutuhkan suatu model dan media yang tepat dalam proses pembelajaran. Model dan media pembelajaran yang baik dapat membantu kegiatan pembelajaran berlangsung dengan baik, sehingga tujuan pembelajaran dapat tercapai. Kegiatan pembelajaran dapat dilakukan dengan berbagai model, dan media pembelajaran. Guru dapat memilih model, dan media pembelajaran yang sesuai dengan pelajaran yang akan dipelajari.

Berdasarkan hasil observasi pada kelas IV SDN 4 Panarung yang berjumlah 21 orang terdiri dari 9 laki-laki dan 12 orang perempuan, peneliti menemukan beberapa masalahan dalam pembelajaran IPA, dalam proses pembelajaran yang dilakukan dikelas yaitu model pembelajaran yang digunakan masih belum bervariasi, kurangnya aktifitas belajar peserta didik saat pembelajaran IPA, kurangannya pemahaman peserta didik terhadap materi pembelajaran IPA, sebagian besar peserta didik menganggap proses pembelajaran IPA kurang menarik, hasil belajar peserta didik pada pelajaran IPA masih dibawah KKM.

Aris Shoimin (2014:166) berpendapat bahwa: Model pembelajaran Scramble merupakan model yang mengajak siswa untuk menemukan jawaban dan menyelesaikan permasalahan yang ada dengan cara membagi akan lembar soal dan lembar jawaban yang disertai dengan alternatif jawaban yang tersedia. Dan model pembelajaran ini merupakan model pembelajaran yang berbentuk permainan acak kata, kalimat, atau faragraf. Sedangkan Rober B. Taylor (Miftahul Huda, 2013:303) berpendapat bahwa: "Scramble merupakan salah satu model pembelajaran yang dapat 
meningkatkan konsentrasi dan kecepatan berfikir siswa untuk menjawab soal namun masih dalam kondisi acak".

Berdasarkan penjelasan diatas, bahwa model pembelajaran Scramble adalah model pembelajaran yang melatih konsentrasi peserta didik dalam menemukan alternatif jawaban secara benar karena kata-kata ataupun jawaban yang telah diberikan akan di acak oleh guru sehingga peserta didik harus berfikir secara logis.

Aris Shoimin (2014:167-168) langkah-langkah pelaksanaan model pembelajaran Scramble, yaitu:

I. Guru menyiapkan bahan dan media yang akan digunakan dalam pembelajaran

2. Guru meyiapkan kartu sebanyak kelompok yang dibagi

3. Guru mengatur hal-hal yang mendukung proses belajar mengajar misalnya, mengatur tempat duduk sesuai kelompok yang telah dibagi

4. Guru melakukan diskusi kelompok

5. Guru menyampaikan kepada siswa masalah tugas yang diberikan

6. Guru meminta siswa berdiskusi dengan kelompoknya

7. Guru membuat kesimpulan dan melakukan evaluasi, secara berkelompok dan setelah itu menutup pelajaran.

Sedangkan Miftahul Huda (2013:304-305) langkah-langkah pelaksanaan model pembelajaran Scramble, yaitu:

I. Guru menyajikan materi sesuai topik

2. Guru membagikan lembar kerja bagi siswa dengan jawaban yang diacak susunannya

3. Guru memberi durasi tertentu untuk mengerjakan soal

4. siswa mengerjakan soal berdasarkan waktu yang telah ditentukan guru

5. Guru mengecek durasi waktu sambil memeriksa pekerjaan siswa

6. Jika waktu pekerjaan soal sudah habis, siswa wajib mengumpulkan lembar pekerjaan kepada guru

7. Guru melakukan penilaian baik dikelas maupun di rumah

8. Guru memberi apresiasi rekognisi kepada siswa yang berhasil.

Berdasarkan pendapat kedua para ahli di atas maka dapat disimpulkan bahwa langkah-langkah model pembelajaran Scramble adalah:

I. Guru menyajikan materi sesuai topik

2. Guru menyiapkan bahan dan media yang akan digunakan dalam pembelajaran dan membagikan lembar kerja bagi peserta didik dengan jawaban yang diacak susunannya

3. Guru menyampaikan kepada peserta didik masalah tugas dan membagi peserta didik kedalam beberapa kelompok terdiri dari 4-5 orang dalam satu kelompok

4. Guru meminta peserta didik berdiskusi dengan kelompoknya
5. Guru meminta kepada peserta didik untuk mengerjakan soal berdasarkan waktu yang telah ditentukan

6. Guru mengecek durasi waktu sambil memeriksa pekerjaan peserta didik

7. Guru memberikan apresiasi rekognisi kepada peserta didik yang berhasil menjawab soal yang telah diberikan.

Kelebihan model pembelajaran Scramble antara lain sebagai berikut:

I. Setiap anggota kelompok akan bertanggung jawab atas segala sesuatu yg dikerjakan setiap kelompoknya

2. Memudahkan untuk mencari sebuah jawaban

3. Mendorong peserta didik untuk belajar

4. Kegiatan tersebut dapat mendorong pemahaman peserta didik

5. Melatih untuk disiplin, dan model ini mendorong peserta didik berlomba-lomba untuk maju.

Model pembelajaran Scramble memiliki kekurangan yaitu sebagai berikut:

I. Siswa bisa mencontek jawaban temannya

2. Peserta didik kurang berfikir kritis, kerena pilihan jawaban telah tersedia

3. Siswa dilatih untuk berfikir kreatif meniadakan sikap kreatif siswa

4. Mematikan kreatifitas peserta didik, karena peserta didik hanya menerima model pembelajaran yang telah disediakan pendidik, sehingga kreativitas peserta didik kurang disalurkan.

5. Peserta didik tinggal menerima bahan mentah, kerena guru telah menyediakan bahan mentahnya.

Azhar Arsyad (2013:89), mengatakan bahwa: Media berbasis visual (image atau perumpamaan) memegang peran yang sangat penting dalam proses belajar. Media visual dapat memperlancar pemahaman (misalnya melalui elaborasi, sturuktur, dan organisasi) dan memperkuat ingatan.

Sedangkan Riva dan Sudjana (201 I:8) bahwa: "media Visual ialah tampilan atau lambang-lambang untuk memperjelas makna pesan yang dibicarakan dalam proses pembelajaran".

Menurut pendapat diatas bahwa media Visual ialah media yang hanya bisa menampilkan sebuah lambang-lambang seperti gambar tanpa adanya suara dan gerak. Karena media ini memegang peran yang sangat penting untuk meningkatkan kemauan peserta didik untuk belajar.

\section{METODE PENELITIAN}

Penelitian ini menggunakan rancangan metode Penelitian Tindakan Kelas (PTK), penelitian yang dilaksanakan secara sistematis, dan terencana, maksudnya setiap langkah yang 
dilakukan dalam PTK harus dilakukan dengan terprogram dan penuh kesadaran sehingga dapat diketahui aspek-aspek mana yang perlu ditingkat dan diperbaiki demi ketercapaian kompetensi yang ditargetkan dan peneliti tindakan kelas ini bertujuan untuk meningkatkan kualitas praktik pembelajaran dan hasil pembelajaran di kelas dengan menggunakan model pembelajaran Scramble berbantuan media Visual peserta didik kelas IV SDN 4 Panarung.

Suatu penelitian akan menghasilkan kesimpulan yang tepat, apabila menggunakan jenis penelitian yang tepat dan benar sesuai dengan masalah yang diteliti, situasi, dan kondisi saat penelitian tersebut dilakukan. Berdasarkan masalah yang dikemukakan dalam penelitian ini menggunakan jenis penelitian tindakan kelas.

Kehadiran peneliti mutlak diperlukan karena kehadiran peneliti sangat diperlukan dalam setiap kegiatan ditempat penelitian. Peneliti berperan sebagai perencana, pelaksana tindakan, peneliti bertindak sebagai pengajar atau guru model yang bertugas membuat rancangan pelaksanaan pembelajaran (RPP) sekaligus menyampaikan bahan ajar selama pembelajaran. Di samping itu, penelitian mengumpulkan dan menganalisis data serta sebagai pelapor hasil penelitian. Sebelum melakukan pengamatan, pada observer dilatih terlebih dahulu agar memahami materi pengamatan dan media Visual yang akan diterapkan beserta materi yang akan di ajarkan kepada peserta didik.

Subjek penelitian dalam penelitian ini adalah peserta didik kelas IV SDN 4 Panarung untuk dijadikan sebagai sumber informasi yang dibutuhkan dalam pengumpulan data penelitian peserta didik berjumlah 21 yang terdiri dari 9 laki-laki dan 12 perempuan. Pengumpulan data yang diperoleh pada penelitian ini dilakukan melalui pengamatan (observasi) dan tes hasil belajar. Penelitian ini menggunakan metode Penelitian Tindakan Kelas (PTK). Analisis data merupakan kegiatan yang dilakukan. Data yang telah dikumpulkan sebelumnya diolah menjadi dua jenis yaitu secara kualitatif dan kuantitatif. Data kualitatif diperoleh dari aktivitas terhadap peneliti dan aktivitas.

\section{HASIL DAN PEMBAHASAN}

Hasil penelitian terlihat dari data berikut ini. Data aktivitas guru dan peserta didik dalam pembelajaran dengan model pembelajaran Scramble berbantuan media Visual.

Tabel I. Data Aktivitas Guru dan Peserta Didik

\begin{tabular}{cc}
\hline \multicolumn{3}{c}{ Aktivitas } \\
\hline Guru & Peserta Didik \\
3,61 & 3,55 \\
\hline
\end{tabular}

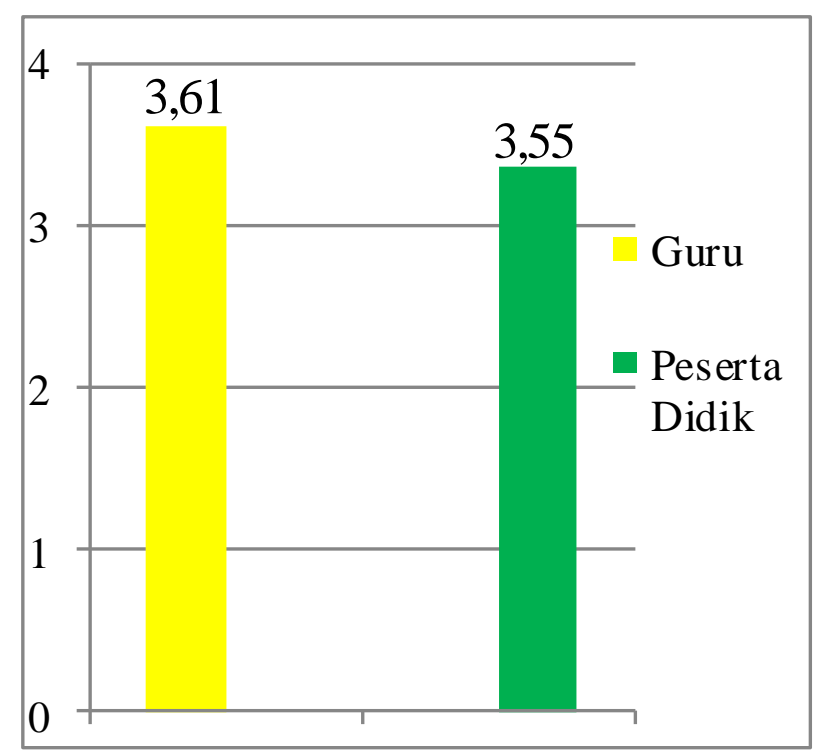

Gambar I. Grafik Aktivitas Guru dan Peserta Didik

Berdasarkan tabel dan grafik tersebut dapat disimpulkan bahwa ada perbedaan antara aktivitas guru dan peserta didik dengan menggunakan model pembelajaran scramble berbantuan media visual, aktivitas guru pada kegiatan awal, kegiatan inti, dan kegiatan akhir mendapatkan skor 3,6I sedangkan aktivitas peserta didik memperoleh skor 3,55 pada aktivitas pembelajaran.

Hasil belajar peserta didik mengalami peningkatan hal tersebut dapat dilihat dari data hasil belajar peserta didik yang diperoleh dari pre test dan post test siklus I. Pada tes awal (pre test), hasil belajar peserta didik memperoleh nilai rata-rata 43 (di bawah KKM 65) dengan ketuntasan klasikal 9,52\% Pada siklus I hasil belajar peserta didik memperoleh nilai rata-rata 70 dengan ketuntasan klasikal 100\% yang memenuhi ketuntasan klasikal $85 \%$ dari hasil penelitian ini. Penggunaan model pembelajaran scramble media visual dalam pelajaran ilmu pengetahuan alam (IPA) pada materi perubahan kenampakan permukaan bumi dan benda langit mampu meningkatkan hasil belajar peserta didik.

Meningkatnya hasil belajar peserta didik dengan menggunakan model pembelajaran scramble berbantuan media visual, karena model pembelajaran ini dapat meningkatkan konsentrasi dan kecepatan berfikir peserta didik peserta didik akan terbantu dalam mencari jawaban semua peserta didik dapat terlibat aktif, kegiatan pembelajaran ini mendorong pemahaman peserta didik terhadap materi pelajarandengan bantuan teman-temannya sesama peserta didik serta melalui penggunaan media visual dapat menarik minat belajar peserta didik hal tersebuat membuat peserta didik terfokus pada materi atau penjelasan dari guru. 
Tabel 2. Hasil Belajar Peserta Didik Pada Tes Awal dan Siklus I

\begin{tabular}{ccccc}
\hline No & Data & $\begin{array}{c}\text { Skor } \\
\text { Rata-rata }\end{array}$ & $\begin{array}{c}\text { Skor } \\
\text { Maksimal }\end{array}$ & $\begin{array}{c}\text { Persentase } \\
\text { Ketuntasan Klasikal }\end{array}$ \\
\hline 1 & Tes Awal & 43 & 100 & $9,52 \%$ \\
2 & Siklus I & 70 & 100 & $100 \%$ \\
\hline
\end{tabular}

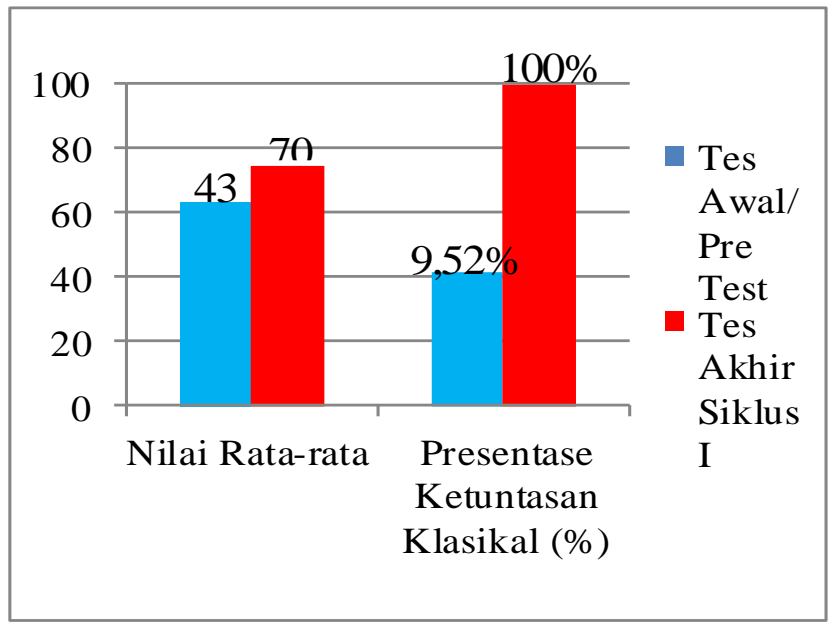

Gambar 2. Grafik Presentase Peningkatan Hasil Belajar IPA saat Tes Awal dan Tes Akhir Siklus

Berdasarkan hasil penelitian tersebut dapat disimpulkan bahwa ada peningkatan hasil belajar IPA peserta didik dengan menggunakan model pembelajaran Scramble berbantuan media Visual. Pada tes awal (pre test), hasil belajar peserta didik memperoleh skor rata-rata 43 dengan ketuntasan klasikal 9,52\%. Kemudian pada silkus I saat diberikan post test hasil belajar peserta didik memperoleh skor rata-rata 70 dan telah mencapai KKM 65, dengan ketuntasan klasikal 100\% yang telah memenuhi ketuntasan klasikal 85\%. Hal ini dapat disimpulkan bahwa model pembelajaran Scramble berbantuan media Visual dalam proses pembelajaran IPA dapat meningkatkan aktivitas peserta didik saat proses pembelajaran berlangsung dan dapat meningkatkan hasil belajar peserta didik.

Penelitian ini bukan untuk membandingkan antar siklus tetapi peneliti memberikan perbandingan pada saat peneliti tidak mengajar dengan menggunakan model pembelajaran Scramble berbantuan media Visual yang tentunya menjadi faktor penyebab hasil belajar peserta didik meningkat.

\section{KESIMPULAN}

Aktivitas belajar peserta didik pada kategori baik mejadi lebih baik dalam pembelajaran IPA dengan menggunakan model pembelajaran scramble berbantuan media visual di kelas IV SDN 4 Panarung tahun pelajaran 2017/2018. Peserta didik berperan aktif, termotivasi, saling bekerjasama dengan meningkatkan konsentrasi dan kecepatan berfikir selama proses pembelajaran pada siklus I. Adapun hasil pengamat aktivitas guru pada proses pembelajaran yang dilakukan oleh pengamat I dan pengamat II selama proses pembelajaran ilmu pengetahuan alam (IPA) pada siklus I rata-rata aktivitas guru yaitu 3,6I dengan kriteria sangat baik dan rata-rata aktivitas peserta didik yaitu 3,55 dengan kriteria sangat baik. Ada peningkatan hasil belajar IPA peserta didik kelas IV di SDN 4 Panarung tahun pelajaran 2017/2018 setelah menggunakan model pembelajaran scramble dengan berbantuan media visual. $\mathrm{Hal}$ ini ditunjukkan dengan hasil belajar yang dilihat melalui skor rata-rata kelas pada tes awal yaitu 43 dan persentase ketuntasan belajar peserta didik secara klasikal yaitu 9,52\% dengan kriteria tidak tercapai. Pada siklus I skor rata-rata kelas yaitu 70 dan persentase ketuntasan belajar peserta didik secara klasikal yaitu $100 \%$, dari kriteria yang telah ditentukan yaitu untuk KKM adalah 65 dan kriteria ketuntasan secara klasikal $85 \%$ dengan kategori tercapai.

\section{DAFTAR PUSTAKA}

Aris, Shoimin. (2014). 68 Model Pembelajaran Inovatif Dalam Kurikulum 2013. Jakarta: PT Ar-Ruzz Media.

Azhar, Arsyad. (20I3). Media Pembelajaran. Jakarta: PT Raja Grafindo Persada.

Harsya. (20I2). Media Pendidikan. Jakarta: PT Raja Grafindo Persada.

Kosasih, Optimalisasi Media Pembelajaran, Jakarta: Grasindo, 2007)

Miftahul, Huda. (20/3). Model-Model Pengajaran dan Pembelajaran. Jogyakarta: PT Pustaka Belajar Offset.

Rayandra, Asyhar. (2012). Kreatif Mengembangkan Media Pembelajaran. Jakarta:

Riva \& Sudjana. (20I I). Media Pembelajaran. Bandung: Sinar Baru Algensindo.

Sri, Anitah. (20I2). Media Pembelajaran. Jakarta: PT Bumi Aksara.

Suyatno. (2009). Menejemen Pembelajaran Inovatif. Jakarta: Mesmedia Buana Pustaka 